\title{
Pasture and stock management of Californian thistle
}

\author{
R.B. MITCHELL ${ }^{1}$, J.M. KEOGHAN ${ }^{2}$ and A. RAHMAN ${ }^{3}$ \\ ${ }^{1} 2$ Esk Place, Mosgiel \\ ${ }^{2}$ Box 35, Rolleston \\ ${ }^{3}$ AgResearch, Ruakura Research Centre, Private Bag 3123, Hamilton
}

\begin{abstract}
A combination of mowing and grazing by sheep has been shown to successfully control Californian thistle (Cirsium arvense) in small plot and paddock scale trials. Between 1994 and 2000 the technique was applied to 15 paddocks on nine farms in Otago, Southland and MidCanterbury. Thistle-infested pastures were mown as low as possible, usually in December after weaning. Thistles at this time were up to $1 \mathrm{~m}$ tall at the mid to late bud stage. Mobs of at least 350 ewes/ha were introduced at mowing or a day or two before, with all mown herbage eaten within 3 days. Pastures were re-grazed with this or similar sized mobs at approximately threeweek intervals to remove re-growth thistles which had emerged since the previous grazing and before their spines hardened. Each grazing forced the plant's root system to produce a new crop of aerial shoots and this ultimately used up the root reserves causing the thistles to die. The farmers involved were responsible for implementing recommendations on mob size, time and length of grazing. Three or four repeat grazings markedly reduced thistle numbers the following summer, resulting in almost complete elimination by autumn in year two after the programme was repeated. With fewer grazings in year one, control took longer. The grazing regime had no apparent effect on ewe health and resulted in improved pasture quality.
\end{abstract}

Keywords: Californian thistles, mob size, repeat grazing, thistle numbers

\section{Introduction}

Californian thistle (Cirsium arvense) is possibly the most invasive, persistent weed common to animal fattening properties in New Zealand. Reducing thistle presence has been shown to benefit stock live-weights and increase financial gain (Hartley \& James 1979). Prickly aerial growth is supported and renewed by vigorous underground roots. This root system contains numerous root buds, some of which are activated each time the above ground vegetation is removed or damaged by either stock, machinery or herbicide. Such renewal however uses up root reserves. By continued and regular removal of the above ground vegetative growth, the capacity of the root system to form and produce new bud growth is gradually reduced until the roots are killed (Hartley et al.1984; Hartley \& James
1979; Hartley \& Thomson 1981; Mitchell \& Abernethy 1993, 1995; Bourdôt et al. 1998).

Californian thistles are a widespread problem in Otago and Southland. In a 1989 survey of 120 farms, carried out by Balclutha and Gore farm consultants, it was estimated that on average $33 \%$ of each farm surveyed had a Californian thistle problem. Loss of production and cost of control was estimated at $\$ 3,500$ per farm per annum. In another survey in the same area, van Toor \& Stuck (1993) estimated on average 10 hectares of pasture on each farm surveyed were adversely affected by the presence of Californian thistle

Translocated herbicides are traditionally used to control Californian thistles (Hartley \& James 1979; Hartley \& Thomson 1981; Meeklah \& Mitchell 1984) but control can be extremely variable. MCPA and MCPB are most commonly used in pasture but MCPA can reduce the clover content of grazing pasture with subsequent negative effects on the weight gain of young lambs (Lewis 1956, 1957; Hartley 1983).

Research trial results have shown that Californian thistles can be reduced almost to the point of elimination by a combination of mowing and grazing designed to deplete root reserves and eventually kill the plant. In a trial at Dacre in Southland in 1991/92 mowing followed by hard or lax rotational grazing or MCPB followed by hard rotational grazing reduced thistle numbers by $99 \%$ over 2 years (Mitchell \& Abernethy 1993). In a later trial, two annual mowings and 7 repeat grazings over 2 growing seasons reduced thistle numbers by $95 \%$ (Mitchell \& Abernethy 1995). In the latter trial, on average, $72 \%$ of available pasture was eaten at each grazing in mown paddocks compared to $57 \%$ in unmown paddocks. There was also $30 \%$ more feed available in the mown paddocks than in the un-mown paddocks at the beginning of each repeat grazing.

In lowland Otago and Southland, Californian thistle shoots begin to emerge in late spring and as they grow, prickles begin to harden and consequently impede the ability of stock to graze pasture growing close to the thistle base. Ewes will sometimes graze the foliage and flower buds of mature plants but this has little effect on thistle survival. The mow/graze technique trialled for Californian thistle control began when mature ewes became available after weaning, usually in mid to late December. At this time the thistles (at the late bud stage) 
were mown as low as possible and ewes (at least 350/ha to apply the necessary grazing pressure) introduced to graze the pasture, utilize and clean up the cut vegetation. New aerial shoots emerged rapidly following mowing and were grazed again before thistle spines began to harden, usually within 16 to 21 days. Further regular grazings were carried out as often as possible before tupping in autumn.

The aim of the work reported here was to investigate the effectiveness of the technique when it was up-scaled for on-farm use.

\section{Methods}

Between 1995 and 2000, fifteen paddocks on nine farms were mown and then grazed by ewes between weaning in December and mating in March/April. Seven farms were in lowland Southland and South Otago and two in the Mid Canterbury foothills. All were primarily fattening units with lamb and wool the major source of revenue.

In year one of the Californian thistle control programme, the paddocks were mown with disc type mowers and mob grazed. On two farms, paddocks were spray/topped with glyphosate $(180 \mathrm{ml}$ ai/ha) and grazed before mowing. Paddock size ranged from 2 to 40 ha and the stocking rate varied but in each case was sufficient to eat the available vegetation in one to three days (Tables 1 and 2). At mowing the thistles were up to $1 \mathrm{~m}$ tall, and the majority were at the green bud stage.

To assess the impact of the technique on thistle survival the number of stems within four or five permanently marked 1 x $30 \mathrm{~m}$ areas per paddock was counted before mowing and between grazings over two growing seasons. This measurement was repeated in the following spring and in some cases again in the autumn. On those farms ( 1 and 2 (Table 2)) where the technique was begun in 1994 and thistles completely eliminated, thistle numbers were monitored until April 2000. Multiple re-growth from the base of a mown stalk was counted as a single stem. Each farmer was responsible for implementing the technique on their properties based on recommendations, regarding timing and intensity of grazing, made by the senior author and based on earlier research (Mitchell \& Abernethy 1993, 1995). The paddocks were grazed during winter according to usual farm management.

Table 1 Dates of mow/graze and number of repeat grazings and ewe mob size.

\begin{tabular}{|c|c|c|c|c|c|c|}
\hline \multirow[b]{2}{*}{$\begin{array}{l}\text { Compliance } \\
\text { Farm }\end{array}$} & \multirow[b]{2}{*}{$\begin{array}{l}\text { Area } \\
\text { (ha) }\end{array}$} & & \multicolumn{2}{|c|}{$\begin{array}{l}\text { Management } \\
-- \text { Year } 1--\end{array}$} & \multicolumn{2}{|c|}{-- Year 2-- } \\
\hline & & $\begin{array}{c}\text { Stocking rate } \\
\text { (sheep/ha) }\end{array}$ & $\begin{array}{l}\text { Mow/ } \\
\text { grazed }\end{array}$ & $\begin{array}{c}\text { Repeat } \\
\text { grazings }\end{array}$ & $\begin{array}{l}\text { Mow/ } \\
\text { grazed }\end{array}$ & $\begin{array}{l}\text { Repeat } \\
\text { grazings }\end{array}$ \\
\hline \multicolumn{7}{|c|}{ High (regular grazing) } \\
\hline 1 & 2.8 & 570 & J an 95 & 2 & Dec 95 & 2 \\
\hline 1 & 2.5 & 640 & Dec 95 & 3 & J an 97 & 2 \\
\hline 2 & 4.5 & 420 & Dec 94 & 4 & Dec 95 & 3 \\
\hline 2 & 3.0 & 420 & Dec 95 & 4 & Jan 97 & 2 \\
\hline 3 & 2.0 & 600 & Dec 96 & 5 & not mown & 2 \\
\hline 4 & 4.0 & 400 & Jan 97 & 4 & J an 98 & 2 \\
\hline 5 & 2.0 & 425 & Jan 99 & 4 & not mown & $\operatorname{lax}$ \\
\hline 5 & 2.0 & 425 & Jan 99 & 4 & not mown & $\operatorname{lax}$ \\
\hline \multicolumn{7}{|c|}{ Moderate (irregular grazing) } \\
\hline 2 & 4.0 & $350-500$ & Dec 96 & 3 & Dec 97 & 2 \\
\hline & & & $\begin{array}{l}\text { Dec } 96 \\
\text { Jan } 97\end{array}$ & & Mar 98 & \\
\hline $2^{*}$ & 4.0 & & as above & & & \\
\hline $4^{*}$ & 6.0 & 270 & $\begin{array}{l}\text { Jan } 97 \\
\text { Feb } 97\end{array}$ & 4 & J an 98 & 2 \\
\hline 4 & 4.0 & 400 & J an 97 & 3 & J an 98 & 2 \\
\hline 6 & 2.0 & $250 / 500$ & Jan 95 & 2 & Jan 96 & 2 \\
\hline 7 & 1.5 & & Jan 99 & 3 & Feb 00 & irregular \\
\hline 8 & 40.0 & 375 & J an 98 & 3 & Jan 99 & 1 \\
\hline \multicolumn{7}{|c|}{ Low (irregular grazing and low stocking rate) } \\
\hline $2^{\dagger}$ & 5.0 & variable & $\begin{array}{l}\text { Jan } 97 \\
\text { Nov } 97\end{array}$ & & $\begin{array}{l}\text { Jan } 98 \\
\text { Mar } 98 \\
\text { Mar } 98 \\
\text { Dec } 99\end{array}$ & \\
\hline 9 & \multicolumn{5}{|c|}{ (incl. lambs and cattle) } & 2 \\
\hline
\end{tabular}

* Includes application of glyphosate (spray topping).

† Untreated reference paddock (control). 
Table 2 Number of Californian thistle stems per $\mathrm{m}^{2}$ (SEM) at the beginning and end of each growing season.

\begin{tabular}{|c|c|c|c|c|c|c|c|}
\hline \multicolumn{2}{|c|}{ Compliance } & \multicolumn{6}{|c|}{-------------- Thistle stems $/ \mathrm{m}^{2}--------------$} \\
\hline \multirow[t]{2}{*}{ Farm } & \multirow{2}{*}{$\begin{array}{c}\text { Area } \\
\text { (ha) }\end{array}$} & \multicolumn{2}{|c|}{ - - Season 1-- } & \multicolumn{2}{|c|}{-- Season $2--$} & \multicolumn{2}{|c|}{-- Season $3--$} \\
\hline & & Dec & April & Dec & April & Dec & April \\
\hline \multicolumn{8}{|l|}{ High } \\
\hline 1 & 2.8 & $10(0.7)$ & $0.5(0.2)$ & $2.0(0.4)$ & $0(0)$ & 0 & \\
\hline 1 & 2.5 & $12(1.5)$ & Sprayed & $4.0(0.5)$ & $0.05(0.03)$ & 0 & \\
\hline 2 & 4.5 & $10(1.1)$ & $2.3(0.3)$ & $0.6(0.2)$ & 0 & 0 & \\
\hline 2 & 3.3 & $5.3(0.6)$ & $6.3(1.2)$ & $7.7(1.1)$ & $0.2(0.1)$ & 0 & \\
\hline 3 & 2.0 & $11(1.6)$ & $0.3(0.2)$ & $0.1(0.04)$ & 0 & 0 & \\
\hline 4 & 4.0 & $8(0.4)$ & $0.5(0.1)$ & $0.3(0.1)$ & $0.01(0)$ & 0 & \\
\hline 5 & 2.0 & $11(1.9)$ & $9.0(2.0)$ & $0.5(0.1)$ & 0 & 0 & \\
\hline 5 & 2.0 & $16(1.1)$ & $1.7(0.7)$ & $1.0(0.4)$ & $0.01(0.01)$ & 0 & \\
\hline \multicolumn{8}{|c|}{ Moderate } \\
\hline 2 & 4.0 & $12(1.7)$ & $6.0(1.4)$ & $3.0(0.8)$ & $0.1(0.1)$ & $2(0.9)$ & $0.7(0.46)$ \\
\hline $2^{*}$ & 4.0 & $11(1.3)$ & $6.0(1.0)$ & $1.25(0.2)$ & $0.01(0.01)$ & $0.2(0.1)$ & $0.1(0.06)$ \\
\hline $4^{*}$ & 6.0 & $12(1.0)$ & $6.0(0.5)$ & $3.0(0.3)$ & $0.3(0.05)$ & $0.3(0.04)$ & $0.3(0.1)$ \\
\hline 4 & 4.0 & $10(2.7)$ & $4.4(1.6)$ & $2.0(0.5)$ & $0.2(0.1)$ & $0.3(0.2)$ & $0.2(0.2)$ \\
\hline 6 & 2.0 & $22(2.1)$ & $6.5(2.1)$ & $10.0(2.9)$ & $1.5(0.8)$ & $0.5(0.3)$ & 0 \\
\hline 7 & 1.5 & - & $6.0(3.7)$ & $4.1(1.6)$ & $2.5(1.4)$ & excl. from study & \\
\hline 8 & 40.0 & $10(1.7)$ & $3.7(0.9)$ & $4.1(0.7)$ & $1.0(0.4)$ & $0.5(0.2)$ & \\
\hline \multicolumn{8}{|l|}{ Low } \\
\hline $2^{\dagger}$ & 5.0 & $6(1.1)$ & $6.0(1.0)$ & $6.8(1.1)$ & $5.0(1.4)$ & $5.3(1.0)$ & $7.0(1.4)$ \\
\hline 9 & 5.7 & $10(1.1)$ & $15.0(1.5)$ & $6.0(1.6)$ & $4.0(1.4)$ & excl. from study & \\
\hline
\end{tabular}

\section{Results}

The level of compliance with recommendations varied between farms (Table 1). High compliance was considered to be close adherence to the management recommendations both in terms of regularity of grazing and number of stock used for grazing. Where there was some variation from this (usually with number of grazings or regularity of grazing), compliance was termed moderate but where the recommendations were not closely adhered to, compliance was considered low.

Where the level of compliance with the management recommendations was high, thistle density had in all but two instances been reduced by 67 to $97 \%$ at the end of the first season (Table 2). In one of these cases a marked reduction had occurred by the beginning of season two but in the other no reduction was evident at this time. By the second autumn the densities had been further reduced so that only 0 to $0.4 \%$ of the original densities remained and by the beginning of the third season, no thistles were observed in the measured areas (Table 2). Generally two years of treatment were required to eliminate thistles (Table 2). When only moderate compliance was achieved, thistle numbers were reduced by the end of the first season but only by between 23 and $50 \%$ (Table 2). At the end of the second season thistle control varied from levels comparable to those achieved with high compliance (99.9\%) to $75 \%$ (Table 2). With moderate compliance some thistles remained in spring following the end of season two (Table 2). Where the recommendations were not followed (low compliance) no change was observed by the end of the first season and thistle numbers remained reasonably high after two seasons (Table 2). On the properties where over $95 \%$ control was achieved, less than 20 grazing days were required. Long term monitoring on farms 1 and 2 did not show any thistles in the two years following the control programme. In one case no thistles appeared until three years after the programme ceased. Subsequently very low numbers of thistles were observed in the paddocks.

\section{Discussion and conclusions}

The success of the mow/graze technique for Californian thistle control depends on the repeated removal of newly emerged thistle growth. This investigation showed that the technique could be successfully up-scaled from research trials to on-farm situations. However the degree of thistle control was linked closely with the level of compliance to the recommended paddock management. The farmer must therefore have the resources readily at hand if maximum effect is to be achieved. Paddock size and ewe mob size must be such that all the available vegetation is eaten in one or two days. Mitchell \& Abernethy (1993, 1995) used 350 ewes/ha per day in earlier trials but higher stocking rates were used on most farms in this investigation. The farmers involved noted that neither stock health nor condition was affected by the repeat mob grazings and observed improved pasture with increased clover content as a result of the grazing management. In one instance the farmer monitored the weight of the ewes 
used in the programme (6 grazings in year one) and found after the final grazing that these were on average 1-2 $\mathrm{kg}$ heavier than ewes which were subjected to normal farm management.

At mowing the most advanced Californian thistles should be at the green bud stage. Thistles will be eaten by mature ewes immediately after mowing. As thistles dry out they become unpalatable and can protect later emerging thistle re-growth from being grazed. It is important that stock is immediately on hand, or already in the paddock to optimise the technique

The gap between grazings can vary within a few days but repeat grazings must be completed before thistle spines harden on the new crop of emerging thistles. The first mow/grazing triggers an emergence of fresh Californian thistle shoots, especially at the base of the more mature mown stalks. It is important that this new basal growth is eaten at the first repeat graze and at subsequent grazings until the cut stalks begin to disintegrate. After the third repeat grazing, emerging thistle re-growth is predominantly from root buds and lines of new growth along the roots can clearly be seen. From this stage further repeat grazings have a major weakening effect on the root system.

Repeated mowings without follow-up grazing can also reduce Californian thistle populations (Hartley \& James 1979), and reduce root bio mass (Bourdôt et al.1998) but this does not fully utilise all available vegetation as the mow/graze technique does.

\section{Farmer comments}

"The treated paddocks were rejuvenated with increased ryegrass tillering, less weeds and strong clover. Thistles have stayed away. The inconvenience of any management deadlines is off-set by enjoying thistle-free quality pasture, with no long term ill effects on good condition ewes held to three day shifts."

"After one year $97 \%$ of thistles have been eliminated. Pasture quality is higher and clover content has increased. Consequently, sheep are heavier than in other years. This is an effective, practical method that requires some smart management skills. Time of grazing is critical and must be carried out while prickles are still soft. Also it requires shifting a big ewe mob at just the right time several times a season and a high stocking rate is required."

"In one year we have eliminated most thistles in the first paddocks and pasture quality is excellent"

"The results were better than expected with great Californian thistle reduction, fewer seed heads of poor pasture species and a higher percentage of clovers. Sheep have improved their live-weights and scanned out at $185 \%$. It is a system that requires disciplined management and it is the last grazings which knock out the remaining root systems".

"In an area involving 60 hectares; to date $73 \%$ of the area has either zero or very low thistle density, the remainder having a low density with some heavier patches. Mow low and clean. Thistles are easier to graze after the $2^{\text {nd }}$ or $3^{\text {rd }}$ topping. Minimum of three grazings or toppings, with five being better. Increase in pasture quality can give better lamb growth rates."

\section{ACKNOWLEDGEMENTS}

This investigation was funded by Meat New Zealand (formerly MRDC) and AgResearch Ltd. The authors thank Rick and Peter Cameron, Pat Bowden, Allan Duff, Ian and Heather Smith, Murray and Doreen Peter, Mt. Linton Station, George and Colin Fox, Murray and Linda Harmer and Alister Roberts for participating in this study. Thanks also to Colin Ferguson for assistance preparing the manuscript, and Barbara Barratt, AgResearch.

\section{REFERENCES}

Bourdôt, G.W.; Leathwick.; D.M., Hurrell. G.A.; Saville, D.J. 1998. Relationship between aerial shoot and root biomass in Californian thistle. Proceedings of the New Zealand Plant Protection Conference 51: 28-32.

Hartley, M.J. 1983. Effect of Scotch thistles on sheep growth rates. Proceedings of the New Zealand Weed and Pest Control Conference 36: 86-88.

Hartley, M.J.; \& James, T.K. 1979. Cost benefit of selective control of Californian thistle in pasture. Proceedings of the New Zealand Weed and Pest Control Conference 32: 245-249.

Hartley, M. J.; Little, L.A.; Popay, A.I. 1984. Control of Californian thistle by grazing management. Proceedings of the New Zealand Weed and Pest Control Conference 37: 24-27.

Hartley, M. J.; Thomson, N.A. 1981. Effect and control of Californian thistle in dairy pasture. Proceedings of the New Zealand Grassland Association 43: 104107.

Lewis, K. H. C. 1956. The use of weed killers in relation to fat lamb production. Proceedings of the New Zealand Weed and Pest Control Conference 9: 101105.

Lewis, K.H.C. 1957. The effect of spraying on fat lamb production. Proceedings of the New Zealand Weed and Pest Control Conference 10: 44-47.

Meeklah, F.A.; Mitchell, R.B. 1984. Evaluation of herbicides for control of Californian thistle. Proceedings of the New Zealand Weed and Pest Control Conference 37: 20-23.

Mitchell, R.B.; Abernethy, R. J. 1993. Integrated management of Californian thistle in pasture. 
Proceedings of the New Zealand Plant Protection Conference 46: 278-281.

Mitchell, R.B.; Abernethy, R. J. 1995. The effect of topping and repeat grazings on Californian thistle and pasture production. Proceedings of the New Zealand
Plant Protection Conference 48: 189-193.

van Toor, R.F.; Stuck R.J. 1993. Farmers evaluation of weed and invertebrate pest problems in pasture. Proceedings of the New Zealand Plant Protection Conference 46: 200-205. 